\title{
A GIS-based DRASTIC model for assessing intrinsic groundwater vulnerability in northeastern Missan governorate, southern Iraq
}

\author{
Alaa M. Al-Abadi • Ayser M. Al-Shamma'a • \\ Mukdad H. Aljabbari
}

Received: 26 March 2014/ Accepted: 1 July 2014/Published online: 3 August 2014

(C) The Author(s) 2014. This article is published with open access at Springerlink.com

\begin{abstract}
In this study, intrinsic groundwater vulnerability for the shallow aquifer in northeastern Missan governorate, south of Iraq is evaluated using commonly used DRASTIC model in framework of GIS environment. Preparation of DRASTIC parameters is attained through gathering data from different sources including field survey, geological and meteorological data, a digital elevation model DEM of the study area, archival database, and published research. The different data used to build DRASTIC model are arranged in a geospatial database using spatial analyst extension of ArcGIS 10.2 software. The obtained results related to the vulnerability to general contaminants show that the study area is characterized by two vulnerability zones: low and moderate. Ninety-four percentage $(94 \%)$ of the study area has a low class of groundwater vulnerability to contamination, whereas a total of $(6 \%)$ of the study area has moderate vulnerability. The pesticides DRASTIC index map shows that the study area is also characterized by two zones of vulnerability: low and moderate. The DRASTIC map of this version clearly shows that small percentage $(13 \%)$ of the study area has low vulnerability to contamination, and most parts have moderate vulnerability (about $87 \%$ ). The final results indicate that the aquifer system in the interested area is
\end{abstract}

\footnotetext{
A. M. Al-Abadi $(\square)$

Geology Department, Science College, Basra University, Basra, Iraq

e-mail: alaaatiaa@gmail.com
}

\author{
A. M. Al-Shamma'a - M. H. Aljabbari \\ Geology Department, Science College, Baghdad University, \\ Baghdad, Iraq \\ e-mail: aysermsh@yahoo.com \\ M. H. Aljabbari \\ e-mail: marwan_aljabbari@yahoo.com
}

relatively protected from contamination on the groundwater surface. To mitigate the contamination risks in the moderate vulnerability zones, a protective measure must be put before exploiting the aquifer and before comprehensive agricultural activities begin in the area.

Keywords Vulnerability map · DRASTIC model · ArcGIS $\cdot$ Missan governorate $\cdot$ South of Iraq

\section{Introduction}

The term "vulnerability" is used to describe the degree to which human or environmental systems are likely to experience harm due to perturbation or stress, and can be identified for a specified system, hazard, or group of hazards (Popescu et al. 2008). In hydrogeology, vulnerability assessment typically describes the susceptibility of a particular aquifer to contamination that can reduce the groundwater quality. The concept was first introduced in France by the end of the 1960s to create awareness of groundwater contamination (Vrba and Zaporozec 1994). No single standardized definition for groundwater vulnerability exists; however, the concept describes the relative ease with which the groundwater resource could be contaminated. The National Research Council (1993) defined it as the tendency or likelihood for contaminants to reach a specified position in the groundwater system after introduction at some location above the uppermost aquifer. Two terms are used to describe groundwater vulnerability: intrinsic and specific. Intrinsic vulnerability is the natural susceptibility to contamination based on the physical characteristics of the environment while specific vulnerability is defined as an accounting for the transport properties of a particular contaminant or group of contaminants 
through the subsurface (Jessica and Sonia 2009). The evaluation of vulnerability is a means to gather complex hydrogeological data in such a way that can be used by a non-specialist people such as decision-makers. Vulnerability assessment of groundwater aquifers provides a basis for initially protective measures for important groundwater resources and will normally be the first step in a groundwater pollution hazard assessment and quality, when it interest (Foster 1987). In recent years, vulnerability assessment of groundwater aquifers considered as an essential part for putting suitable plans to protect groundwater aquifers around the world.

Many approaches have been developed for assessing groundwater vulnerability and can be grouped into three major categories (Tesoriero et al. 1998): (1) overly and index methods; (2) methods employing process-based simulation models; (3) statistical methods. In overly and index methods, factors which are controlling movement of pollutants from the ground surface into the saturated zone (e.g., geology, soil, impact of vadose zone, etc.) are mapped depending on existing and/or derived data. Subjective numerical values (rating) are then assigned to each factor based on its importance on controlling pollutants movement. The rated maps are combined linearly to produce final vulnerability map of an area. The groundwater vulnerability evaluated by such methods is qualitative and relative. The main advantage of such methods is that some of the factors controlling movement of pollutants (e.g., net recharge and depth to groundwater table) can be evaluated over large area, which makes them suitable for regional scale assessment (Thapinta and $\mathrm{Hu}-$ dak 2003). With the advent of GIS digital maps technology, adoption of such methods for creating vulnerability maps is an easy task. Several overly and index methods have been developed. The most common one are: the DRASTIC system (Aller et al. 1987), the GOD system (Foster 1987), The AVI rating system (Van Stempvoort et al. 1993), the SINTACS method (Civita 1994), the German method (Von Hoyer and Söfner 1998), the EPIK (Doerfliger and Zwahlen 1997), and the Irish perspective (Daly et al. 2002). Process-based methods and statistical methods are not commonly used for vulnerability assessment because they are constrained by data shortage, computational difficulty, and the expertise required for implementing them.

The objective of this study is to evaluate intrinsic vulnerability of the principal aquifer in northeastern Missan governorate, south of Iraq for both general and pesticides contaminants using the most popular DRASTIC overlay and index method. Delineation of contamination vulnerability zones is a very necessary step to protect and efficient manage aquifer system within the study area.

\section{Description of DRASTIC system method}

DRASTIC system is the most widely method used to evaluate intrinsic vulnerability for a wide range of potential contaminants. It is an overlay and index model designed to produce vulnerability scores by combining several thematic maps. It was originally developed in USA under cooperative agreement between the National Water Well Association (NWWA) and the US Environmental Protection Agency (EPA) for detail hydrogeological evaluation of pollution potential (Rundquist et al. 1991). The word DRASTIC is acronym for most important factors within the hydrogeological settings which control groundwater pollution. Hydrogeological setting is a composite description of all major geologic and hydrogeological factors which affect the groundwater movement into, through, and out of the area. These factors are: depth to water, net recharge, aquifer media, soil media, topography (slope), impact of vadose zone, and hydraulic conductivity. The DRASTIC numerical ranking system contains three major parts: weights, ranges, and ratings.

1. Weights Each DRASTIC factor is evaluated with respect to each other to determine the relative importance of each factor. Each factor is assigned a relative weight range of 1-5 (Table 1). The most significant factor is allocated five; the least significant is allocated one. DRASTIC has two weight classifications, one for normal conditions (standard) and the other for conditions with intense agricultural activity. The last one is called pesticide DRASTIC index and represents a specific case of DRASTIC index. The difference between the two versions of DRATIC is in the assignment of relative weights for the seven DRASTIC factors. All other parts of the two indices are identical. The application of pesticides when combined with sensitive groundwater areas can impose a significant impact of the water quality. Agricultural contaminants such as pesticides will dissolve in the irrigation water and infiltrate through the soil profile.

Table 1 Weights of the factors in the DRASTIC (standard and Pesticides) (after Aller et al. 1987)

\begin{tabular}{lll}
\hline Factor & \multicolumn{2}{l}{ DRASTIC version } \\
\cline { 2 - 3 } & Standard & Pesticides \\
\hline D: Depth to groundwater & 5 & 5 \\
$R$ : Net recharge & 4 & 4 \\
$A:$ Aquifer media & 3 & 3 \\
$S:$ Soil media & 2 & 5 \\
$T:$ Topography & 1 & 3 \\
$I:$ Impact of vadose zone & 5 & 4 \\
$C:$ Hydraulic conductivity of the aquifer & 3 & 2 \\
\hline
\end{tabular}


Table 2 Criteria of the evaluation of the degrees of vulnerability (Civita and De Regibus 1995; Corniello et al. 1997)

\begin{tabular}{ll}
\hline Degree of vulnerability & DRASTIC index \\
\hline$<80$ & Very low \\
$80-120$ & Low \\
$120-160$ & Moderate \\
$160-200$ & High \\
$>200$ & Very high \\
\hline
\end{tabular}

2. Ranges Each factor in DRASTIC assigned ranges or significant media type which may have an impact on pollution potential. These ranges were described in Aller et al. (1987).

3. Rating Each range for each DRASTIC factor is evaluated with respect to each other to determine the relative significance of each range with respect to the impact on pollution potential. The rating for each DRASTIC factor is assigned a value between 1 and 10 . These ratings provide a relative assessment between ranges in each factor. The higher the rating is the more significant on pollution potential. A and I factors assigned a 'typical' rating and a variable rating. The variable rating allows the user to choose either a typical value or to adjust the value based more specific knowledge (Aller et al. 1987).

The final vulnerability index is weighted sum of the seven factors and can be computed using the following formula:

$\begin{aligned} \text { Vulnerability index }= & D_{\mathrm{r}} D_{\mathrm{w}}+R_{\mathrm{r}} R_{\mathrm{w}}+A_{\mathrm{r}} A_{\mathrm{w}}+S_{\mathrm{r}} S_{\mathrm{w}} \\ & +T_{\mathrm{r}} T_{\mathrm{w}}+I_{\mathrm{r}} I_{\mathrm{w}}+C_{\mathrm{r}} C_{\mathrm{w}}\end{aligned}$

where $D, R, A, S, T, I$, and $C$ are the seven factors of the DRASTIC method, w the weight of the factor, and $r$ the rating associated. Values of DRASTIC index vary from 26 to 256 in the case of the DRASTIC pesticides and from 23 to 226 in the case of the DRASTIC standard version. Aller et al. (1987) did not propose any classification for their drastic results, so the vulnerability ranges of the DRASTIC index used in this study correspond to the most commonly used references in the literature (Civita and De Regibus 1995; Corniello et al. 1997) (Table 2).

\section{The study area}

\section{General description}

The study area is located in the northeast of Missan governorate, south of Iraq between $\left(32^{\circ} 03^{\prime} 25.52^{\prime \prime}-32^{\circ} 30^{\prime} 30^{\prime \prime}\right)$ latitude and $\left(47^{\circ} 05^{\prime} 21.16^{\prime \prime}-47^{\circ} 40^{\prime} 53.52^{\prime \prime}\right) \quad$ longitude (Fig. 1). It encompasses an area of $1,856 \mathrm{~km}^{2}$. The topography elevation ranges from 7 to $230 \mathrm{~m}$. The land surface is relatively flat in the central part of the area and it is bounded by Hemrin hills in the northeastern part and Band hill in the north (Fig. 2). The surface elevations of the study area decrease from northeast to southwest. From the geomorphological point of view, the study area is featureless and bounded by the foothill zone in the northeast along the IraqiIranian border. The area is crossed by two streams namely, Teeb and Dewereg. The source of both is Iran territory. The bigger one is Teeb which enters the Iraqi territory at the Teeb town north of the study area and runs from north to south until it ends in Al-Sanaf marsh outside the study area. The other stream is Dewereg which enters the Iraqi territory at Fauqi area and runs from east to northeast until it finishes in Al-Rais marsh. The climate of southern Iraq (including the study area) is characterized by hot, dry summer, cold winter and a pleasant spring and fall. Approximately $90 \%$ of the annual rainfall occurs between November and April, most of it in the winter months from December to March. The remaining 6 months are dry and hot. The low latitude, the western air currents and the Arabian Gulf generally influence the climate of southern Iraq. The average annual temperature is between 23.74 and $26.43{ }^{\circ} \mathrm{C}$ with little variation between the different stations. Temperature higher than $50{ }^{\circ} \mathrm{C}$ is commonly occurring within the study area and temperature below zero occurs very rarely.

\section{Geological and structural settings}

Rocks of uppermost Miocene and Pliocene existed in the study area. These rocks are buried beneath the Mesopotamian plain by thick deposits of Pleistocene and Holocene age. Most part of the study area is covered with fluviatile, lacustrine, and aeolian sediments of recent age. The Bakhtiari Formation (Mukdadiya and Bai Hassan formations) represents the Tertiary age in the study area. The Bakhtiari Formation was first described in Iran. Bellen et al. (1959) introduced the formation in Iraq and later divided it into the lower and upper Bakhtiaria formation. Jassim et al. (1984) replaced the names of upper and lower Bakhtiaria with Mukdadiya and Bai Hassan, respectively. The two formations are strongly diachronous, but can be recognized throughout the foothill and high folded zones. The two formations occur on the southwest flank of Jabal Hemrin to Jabal Faugi along the Iraq-Iran border (Parsons 1956). The Mukdadyia Formation comprises up to $2,000 \mathrm{~m}$ of fining upwards cycles of gravely sandstone, sandstone are red mudstone (Jassim and Goff 2006). The formation is replaced almost totally by the Bai Hassan conglomeratic facies in the high folded zone of NE but not in N Iraq. The Mukdadiya Formation is deposited in fluvial environment 
Fig. 1 Location of the study area

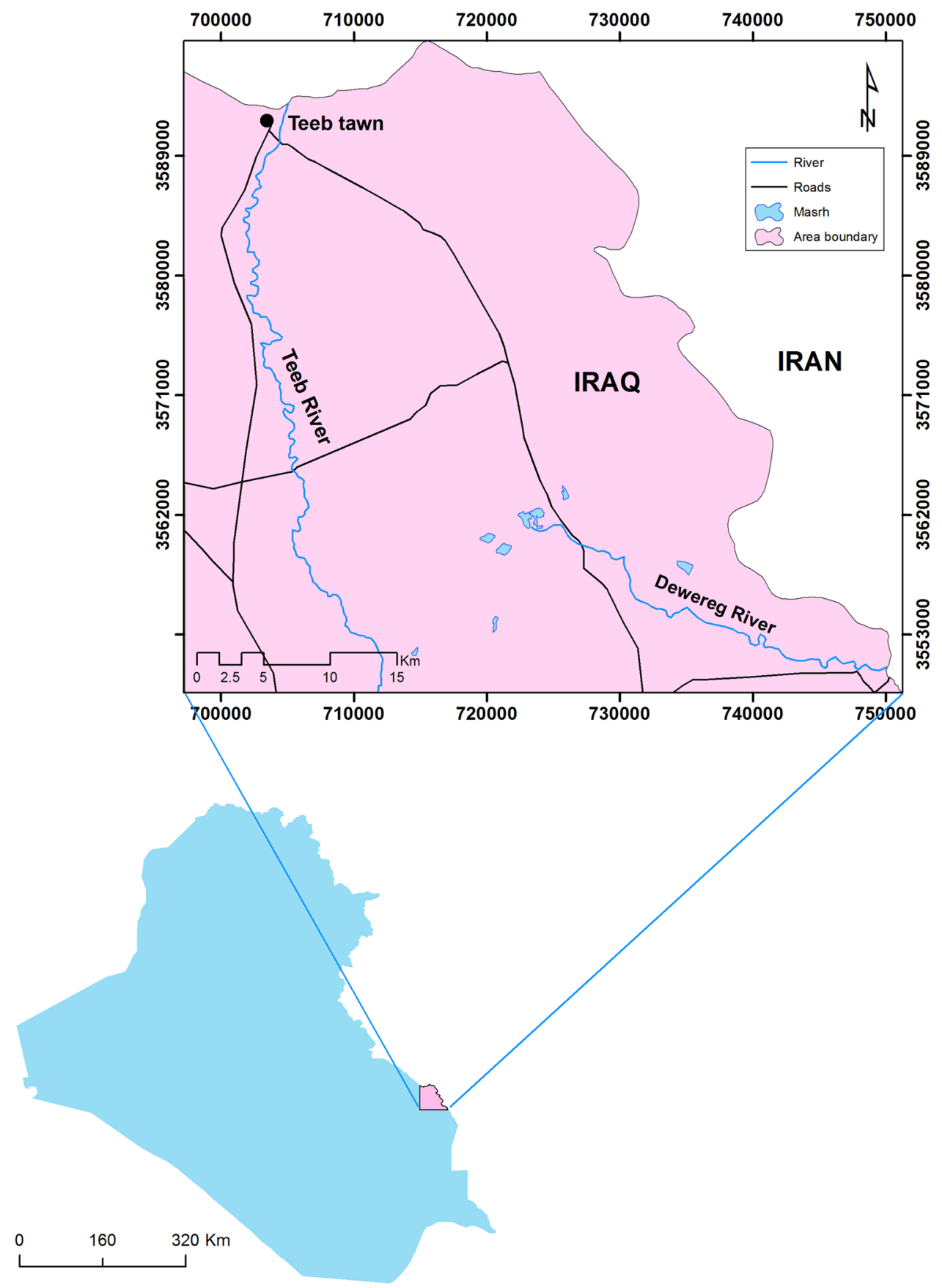

in a rapidly subsiding foredeep basin. The age of the Bakhtiari Formation is Pliocene. The boundary between the lower and upper Bakhtiari is merely a facies change and arbitrarily assumed to be at the base of the first coarse conglomerate. Most part of the study area is covered with different types of Quaternary deposits mainly sand and alluvium deposits of recent and Pleistocene age. The Quaternary sediments are unconsolidated and usually finer grained than the underlying Mukdadiya and Bai Hassan Formations (Bellen et al. 1959; Naqib 1967; Al-Siddiki 1978). Alluvial fan, flood plain, depression fill, and aeolian deposits are the major units of the Quaternary deposits in the study area. Alluvial fans deposits comprise gravel, sand and silty sand. These sediments form a strip along the foothill zone. The maximum thickness of the alluvial deposits may reach to $15 \mathrm{~m}$. Poorly sorted coarse deposits of cobbles and sometimes boulder occur in apical parts passing into finer grained, better sorted layered fluvial sediments. The outer rimes of the fans consist of sand and silt. Gepcrete also developed on the surfaces of some fans. Flood plain sediments comprise layers of silt-clay and clay typically $10-20 \mathrm{~cm}$, but sometimes up to $1 \mathrm{~m}$ thick. 


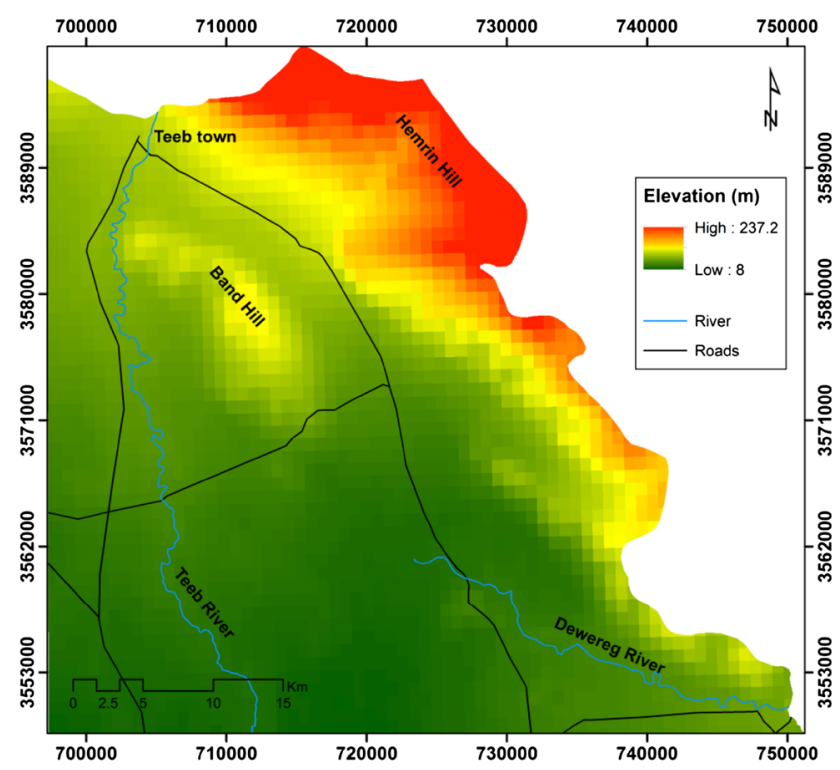

Fig. 2 Elevations (m) in the study area

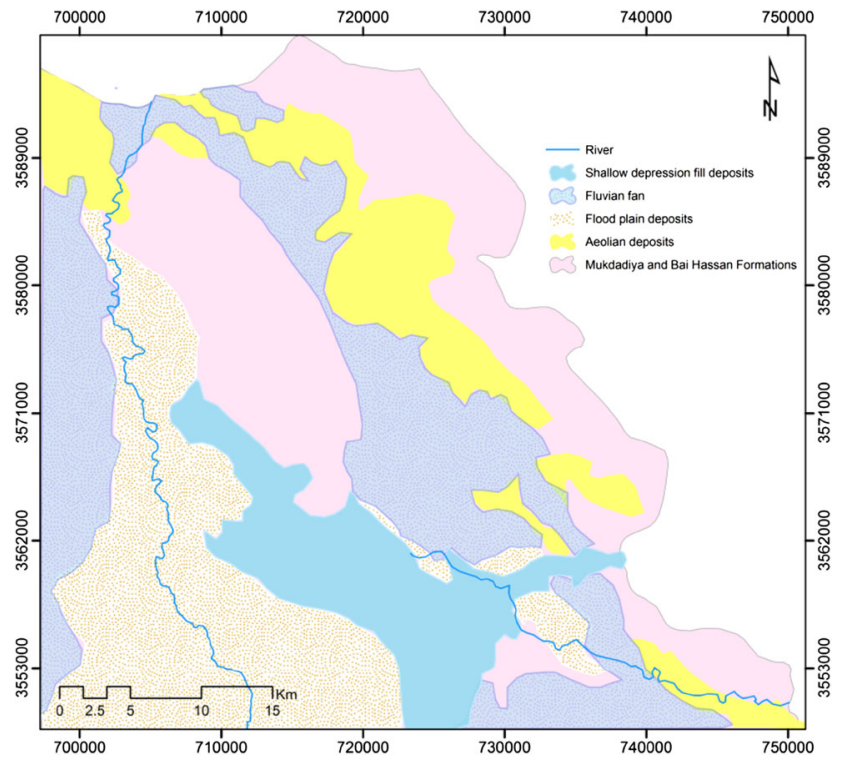

Fig. 3 Geological map of the study area

Depression-filled deposits are generally reddish-brown fine sand, silt and clayey silt. Three types of aeolian sediment are currently found in the area: dust fill-out, mobile and without clear forms and sand dunes. The dust is silty, reddish-brown and calcareous (Khalaf et al. 1985 in Jassim and Goff 2006). Figure 3 shows the geological map of the study area. In general, The Quaternary deposits represent about $72 \%$ while Tertiary sediments extend over $28 \%$ (Fig. 4).

From tectonic point of view, Iraq can be divided into three tectonically different areas: the Stable Shelf Zone with major buried arches and antiforms but no surface

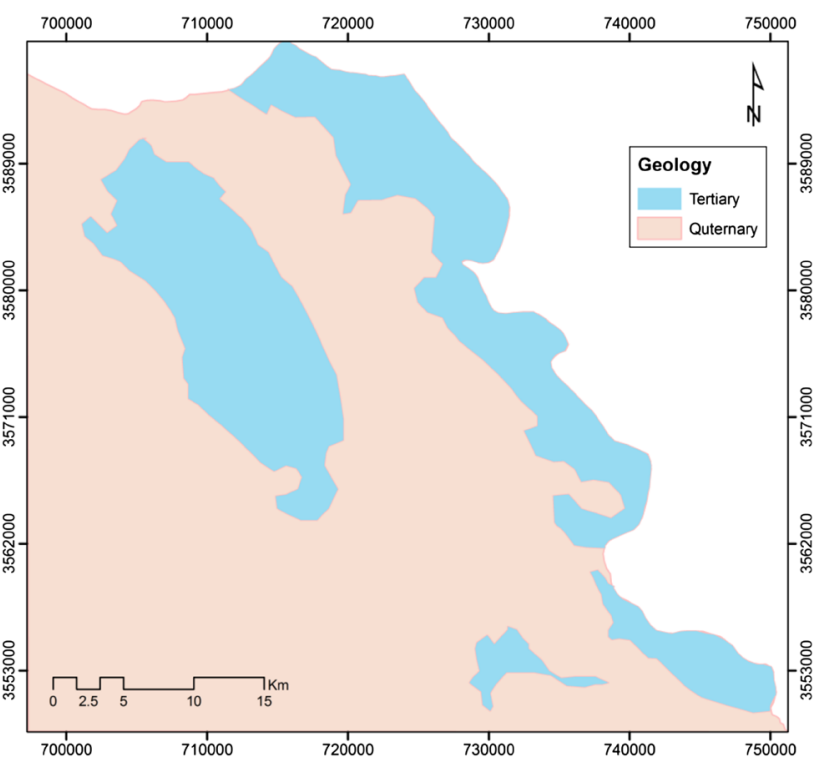

Fig. 4 The age of exposed rocks in the study area

anticlines, the Unstable Shelf with surface anticlines, and the Zagros Suture which comprises thrust sheets of radiolarian chert, igneous and metamorphic rocks (Jassim and Goff 2006). The largest part of the study area lies within the Mesopotamian Zone. The Mesopotamian Zone is the easternmost unit of the stable shelf. It is bounded in the $\mathrm{NE}$ by the folded ranges of pesh-i-kuh in the $\mathrm{E}$, and Hemrin and Makhul in the N. The zone was probably uplifted during the Hercynian deformation, but it subsided from late Permian time onwards. The study area contains buried faulted structure below the Quaternary cover, Separated by broad synclines (Buday and Jassim 1987). The fold structures mainly trend NW-SE in the eastern part of the zone and N-S in the southern part. Small anticline folds are found between Al-Teeb and Shike Fars areas in addition to another fold close to the Al-Swar hills with NW-SE trend. This structure comprised Bazrgan oil field.

Soil

Information on the type of soil is often needed as a basic input in hydrologic evaluation. Mapping soil usually involves delineating soil types that have identifiable characteristics. The delineation is based on many factors such as geomorphologic origin and conditions under which the soil formed (Vieux 2004). A total of 20 samples of soil are collected at a depth of about $75 \mathrm{~cm}$ below the surface after removing the top soil cover. The soil samples are collected in clean polyethylene containers and transported to soil laboratory of civil engineering/Engineering College/University of Basra to carry out grain size analysis. The collected soil samples of the study area are assigned texture 


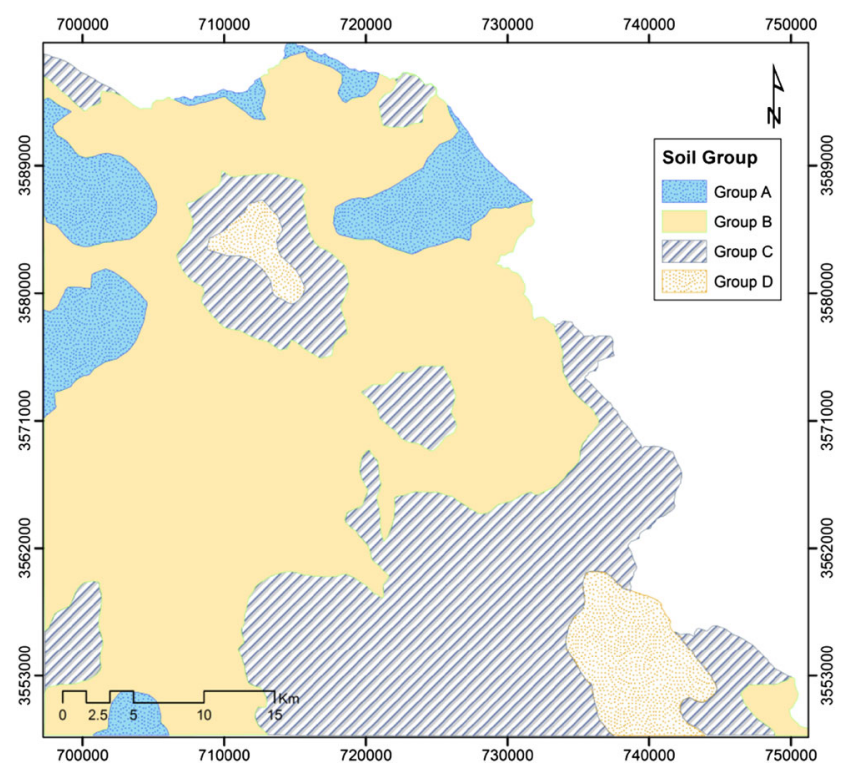

Fig. 5 Map of the soil hydrologic groups

name based on the web-based USDA soil texture calculator (http://soils.usda.gov/technical/aids/investigations/texture/). The soil types in the study area are then converted to soil permeability values based on soil taxonomy. According to this classification each soil hydrological group is assigned a range of values of infiltration rates in $\mathrm{mm} / \mathrm{h}$. The average value of infiltration rates is then interpolated using ordinary kriging techniques in Geostatistical analyst extension of ArcGIS 10.2 to produce the soil hydrological group layer of the study area (Fig. 5).

\section{Hydrogeology}

Geological well logs obtained from the General commission of Groundwater/Ministry of water Resources/Iraq, are used in this study to architecture the aquifer system. Two datasets are available: one is for the general characteristics of a well, including construction data, well owner, and well depth and geographic coordinates. The other is for lithology data including intervals, material types, and well screens position. In addition, information such as depth to groundwater, static water levels, well discharge were also available. Fourteen wells were selected to build aquifer architecture in the study area because these wells have semi-completed record and even distribution of them through the area. According to these information, in addition to screen and lifting pump position in well sections, the aquifer system within the area is subdivided into three aquifers: first aquifer (shallow), principal aquifer (semiconfined), and deep aquifer (confined) (Fig. 6). These aquifers are separated by two less permeable aquitards the hydraulic characteristics of which are unknown. The hydraulic connection between aquifer units is possible and the confined portion of aquifer system is not fully separated. Shallow aquifer is unconfined in nature, less important than the other two aquifers in the study area, and less exploitable. Fine sand and sand with little silt represents the main constituents of this unit. Only few dug wells penetrate this unit of aquifer and extract water for livestock and small farm. Dug wells are shallow and partially penetrate the aquifer; only a few meters with irregular diameters. Although most of net recharge from rainfall goes to this part of aquifer system, water quality is unsuitable for human consumption due to surface salt washing process. Depth to groundwater table ranges from 2 to $5 \mathrm{~m}$. This aquifer is also has limited extension over the study area and might disappear in the west and southwest. The most important aquifer in the study area is the principal aquifer where most of the operating wells penetrate it to some extent. This aquifer is also widespread over the whole area and consists mainly of mixture of gravel and sand with significant amount of silt and clay in some parts of the aquifer. The maximum thickness of the aquifer may reach $42 \mathrm{~m}$ while the minimum thickness is about $20 \mathrm{~m}$ (Fig. 7). It is a semi-confined aquifer where the confined and unconfined occupy 72 and $28 \%$ of the whole study area, respectively (Fig. 8). The latest map is produced through interpolation of upper aquitard thickness over the area validated by the lithological sections of well points. The deep aquifer is found in the eastern part of the area within the Bai Hassan and Mukdadiyah Formations. Only five wells penetrate this part of the aquifer system and no pumps are needed to lift water; the water flows under pressure once the water bearing layer is reached. These flowing wells are operated all the time from morning to night without any controlling device. The groundwater quality of this part of system is very good where the total dissolved solid does not exceed $600 \mathrm{ppm}$. This part of the aquifer consists mainly of gravel and sand. Not enough information is available to draw the spatial distribution of this unit through the area.

The flow direction is from northeast to southwest similar to topographic elevation trend. The north and northeast areas of the study area represent the recharge zone while south and southwest areas represent discharge areas. Figure 9 displays the groundwater depths of the study area. Generally, depths to groundwater levels are shallow, whereby most of the study area having depths in the range of 1.5-15 m. Only a small part of the study area has depths greater than $15 \mathrm{~m}$. Hydraulic conductivity values of the principal aquifer in the study area are acquired from previous studies such as Al-Jaburi (2005) and Lazim (2002). The spatial distribution of hydraulic conductivity over the study area is shown in Fig. 10. The values of this parameter 
Fig. 6 A conceptual model of the study area

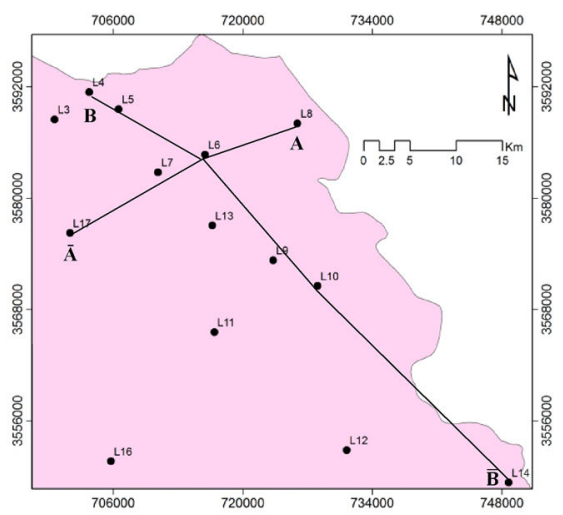

A

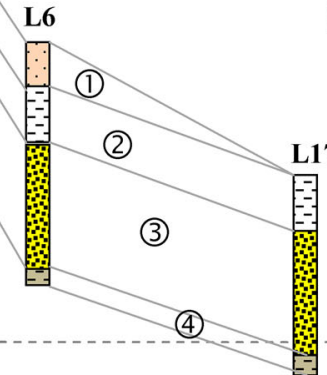

(1) Shallow aquifer

(2) First aquitard

(3) Major aquifer

(4) Second aquitard

$\overline{\mathbf{A}}$

msl

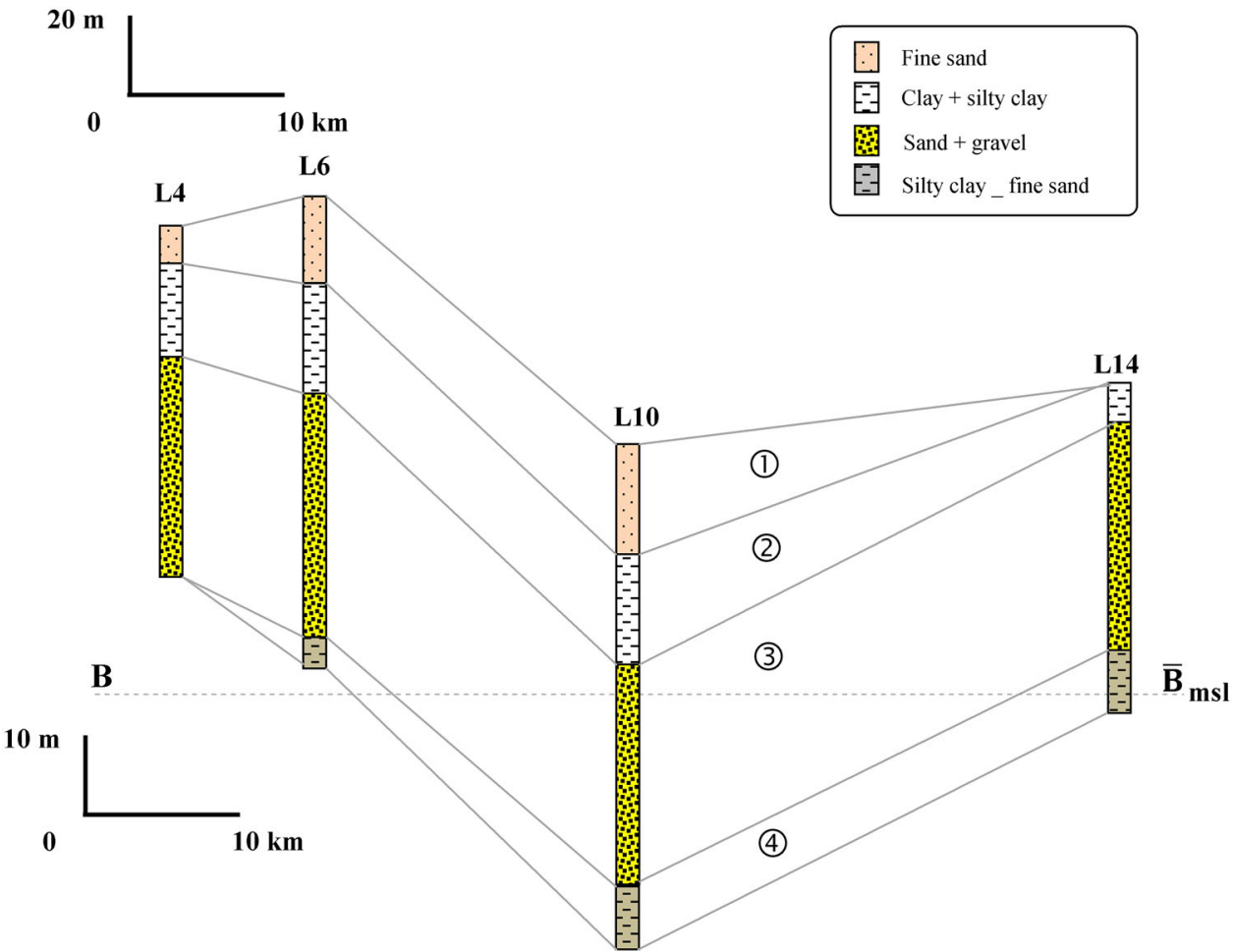

increase from south to north, reflecting the nature of the sediments which changes from Quaternary to Tertiary.

\section{Development of the DRASTIC vulnerability index for the study area}

Due to the presence of industrial and agricultural activities in the study area, the standard and pesticides versions of
DRASTIC model are used in the present study for vulnerability assessment. The different data used to build DRASTIC model are arranged in a geospatial database using spatial analyst extension of ArcGIS 10.2 software. The seven thematic layers are prepared as raster grid of cell size $30 \mathrm{~m}(x, y)$ forming 1,826 and 1,641 columns and rows, respectively. Table 3 shows the DRASTIC rating and weighting values for the study area. The DRASTIC parameters include the following features: 


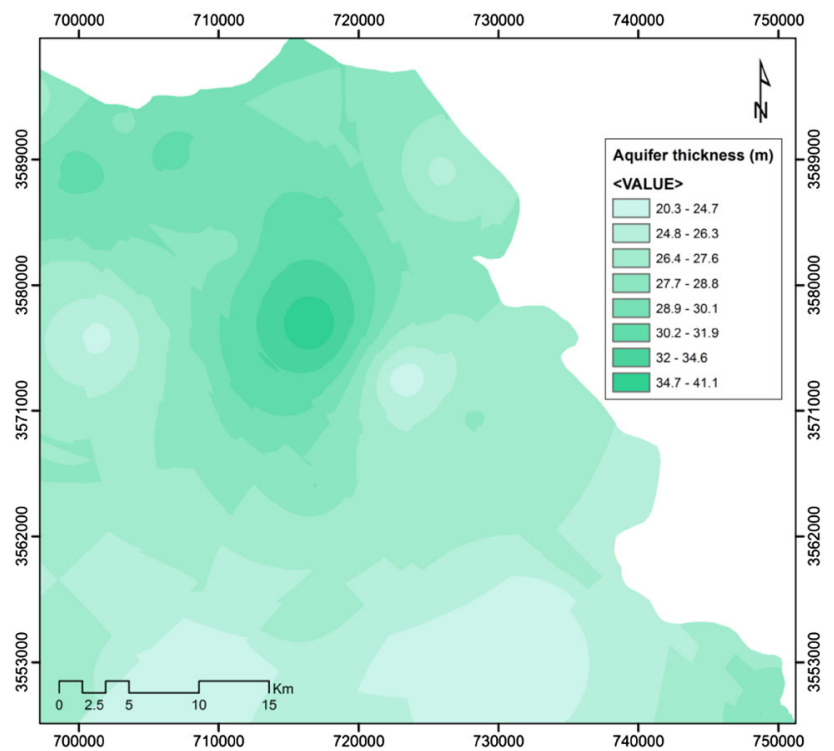

Fig. 7 Principal aquifer thickness (m)

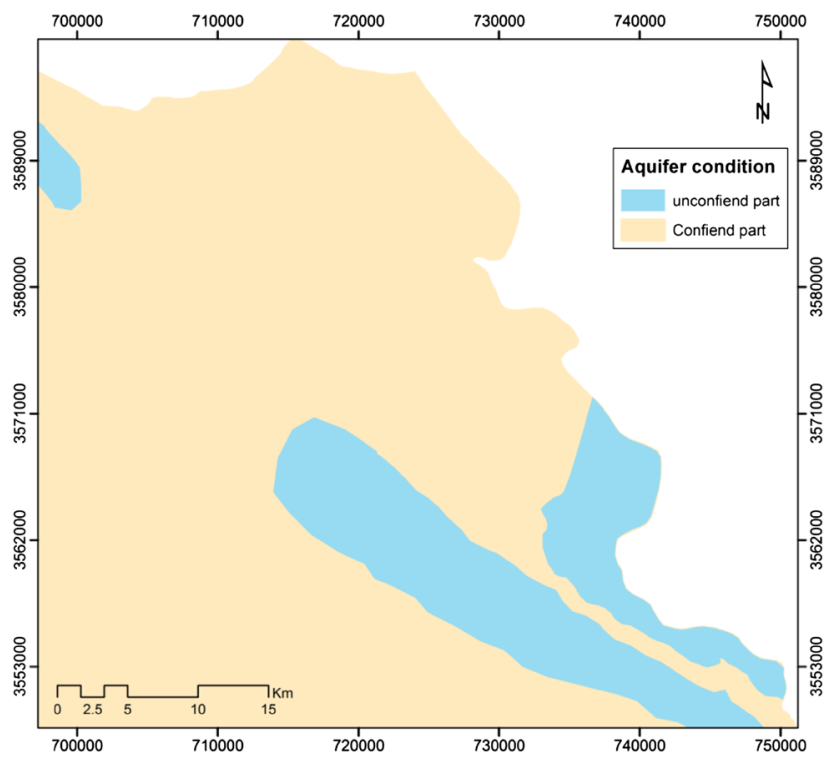

Fig. 8 Aquifer types in the study area

Depth to groundwater levels $(D)$ The groundwater depth for principal aquifer in the study area (Fig. 9) is reclassified into four classes using reclassify command in spatial analyst with regard to DRASTIC rating system (Table 3; Fig. 11a). The depth to groundwater is classified from three (least effect on vulnerability) to nine (most effect on vulnerability).

Net recharge $(R)$ The amount of annual net recharge calculated by mass chloride balance method for the principal aquifer in the study area is less than $50 \mathrm{~mm}$ (AlAbadi 2011). An absolute value of one (Fig. 11b) is assigned to rating value of this factor because of lack of information concerning the spatial distribution of this

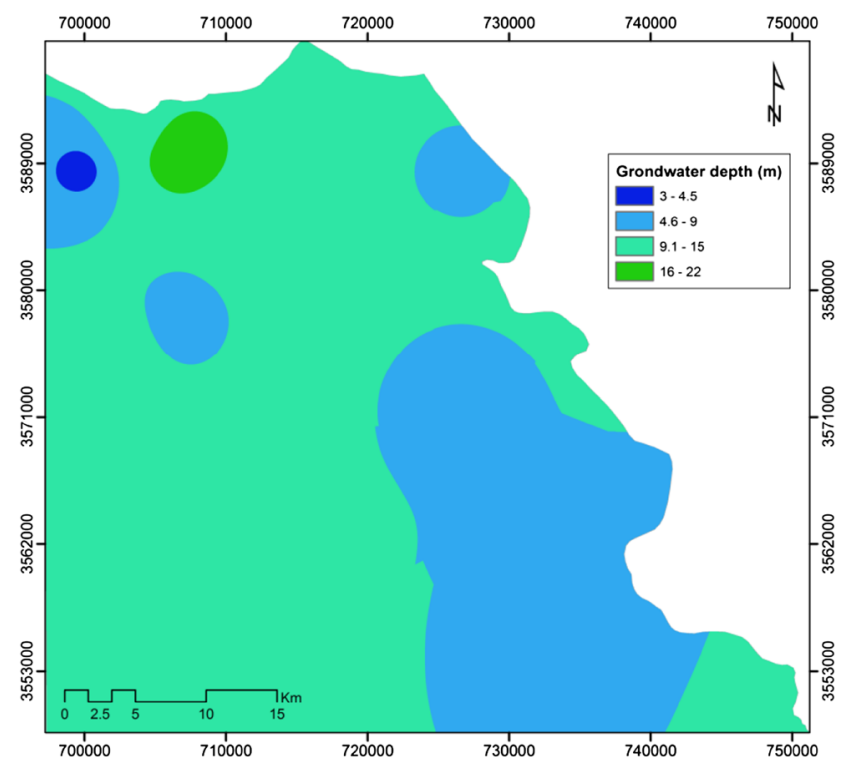

Fig. 9 Depths to groundwater level for the principal aquifer

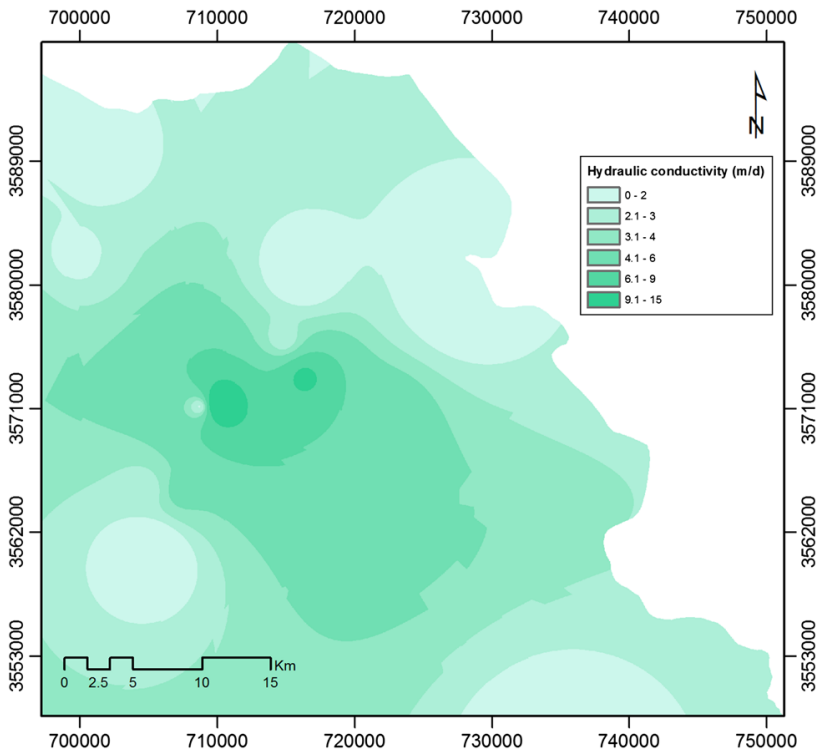

Fig. 10 Spatial distribution of hydraulic conductivity $(\mathrm{m} / \mathrm{s})$

factor over the study area and the nature of confining conditions of principal aquifer which overly partly by a confining unit.

Aquifer media The main lithological constituents of the principal aquifer in the study area are a mixture of gravel and sand with significant amount of silt and clay, therefore the rating value of this media is eight (Fig. 11c).

Soil media The hydrological soil groups of the study area (Fig. 5) represent the soil capabilities to infiltrate water applied where the infiltration capacity of soil decreases from group A to D. According to this fact, the soil media rating map are prepared and shown in (Fig. 11d). These groups are assigned scores of 10, 8, 6, 4 
Table 3 DRASTIC rating and weight values for the study area

\begin{tabular}{|c|c|c|c|c|c|c|}
\hline \multirow[t]{2}{*}{ DRASTIC factors } & \multirow[t]{2}{*}{ Range } & \multirow[t]{2}{*}{ Rating } & \multicolumn{2}{|l|}{ Weight } & \multicolumn{2}{|c|}{ Total weight (rating $\times$ weight) } \\
\hline & & & Standard & Pesticides & Standard & Pesticides \\
\hline \multirow[t]{4}{*}{ Groundwater depth (m) } & $1.5-4.5$ & 9 & 5 & 5 & 45 & 45 \\
\hline & $4.5-9$ & 7 & & & 35 & 35 \\
\hline & $9-15$ & 5 & & & 25 & 25 \\
\hline & $15-22$ & 3 & & & 15 & 15 \\
\hline Net recharge $(\mathrm{mm})$ & $<50$ & 1 & 4 & 4 & 4 & 4 \\
\hline Aquifer media & Sand and gravel & 8 & 3 & 3 & 24 & 24 \\
\hline \multirow[t]{4}{*}{ Soil group } & A & 10 & 2 & 5 & 20 & 50 \\
\hline & $\mathrm{B}$ & 8 & & & 16 & 40 \\
\hline & $\mathrm{C}$ & 6 & & & 12 & 30 \\
\hline & $\mathrm{D}$ & 4 & & & 8 & 20 \\
\hline \multirow[t]{4}{*}{ Topography (slope \%) } & $0-2$ & 10 & 1 & 3 & 10 & 30 \\
\hline & $2-6$ & 9 & & & 9 & 27 \\
\hline & $6-12$ & 5 & & & 5 & 15 \\
\hline & $>18$ & 3 & & & 3 & 9 \\
\hline \multirow[t]{2}{*}{ Impact of vadose zone } & Sand-gravel & 8 & 5 & 4 & 40 & 32 \\
\hline & Silt-clay & 3 & & & 15 & 12 \\
\hline \multirow[t]{3}{*}{ Hydraulic conductivity (m/d) } & $0-4.32$ & 1 & 3 & 2 & 3 & 2 \\
\hline & $4.32-13$ & 2 & & & 6 & 4 \\
\hline & $13-28.5$ & 4 & & & 12 & 8 \\
\hline
\end{tabular}

to reflect the ability of these groups to infiltrate water and other constituents such as contaminants.

Topography (slope) The topography of the study area is obtained from the DEM covering the study area. Slope values $(\%)$ are then calculated from this map using the spatial analyst tools in ArcGIS 10.2. The slope values are rated based on the criteria of DRASTIC model with 10 being the lowest slope (Fig. 11e). Generally, the slope in the study area is low and therefore increases the groundwater vulnerability.

Impact of vadose zone (I) As mentioned before, the principal aquifer in the study area is a semi-confined aquifer where the confined part occupies about $72 \%$ from the study area and the remaining is the unconfined part. The unsaturated zone in the confined part consists mainly of silt and clay while the main constituents of vadose zone of the unconfined part are sand and gravel. Therefore, the vadose zone of the confined and unconfined parts is rated eight and three depending on the criteria of DRASTIC model (Fig. 11f).

Hydraulic conductivity $(C)$ The hydraulic conductivity map of the principal aquifer (Fig. 10) is reclassified according to the criteria of DRASTIC model using reclassify tool in spatial analyst extension of ArcGIS environment (Fig. 11g).

The final vulnerability maps (standard and pesticides DRASTIC versions) of the study area are calculated using raster calculator in spatial analyst tool. The DRASTIC rating from each input layer is multiplied by the weight for that layer and summed to determine the DRASTIC index. The resulted indices are classified according to Table 2 for deriving the classes of vulnerability. Figure 12 a reveals the vulnerability classes for standard and pesticides DRASTIC, respectively. Table 4 shows the areas occupied by each of these classes for standard and pesticides versions of DRASTIC model. The obtained results related to the vulnerability to general contaminants show that the study area is characterized by two vulnerability zones: low and moderate. The DRASTIC index ranges between 78 and 129. Table 4 shows that $94 \%$ of the study area has a low class of groundwater vulnerability to contamination, whereas a total of $6 \%$ of the study area has moderate vulnerability. A very wide area (96\%) is located within the low vulnerability class which may be attributed to the impact of vadose zone and the low values of hydraulic conductivity of the aquifer. The pesticides DRASTIC index map (Fig. 12b) shows that the study area is also characterized by two zones of vulnerability: low and moderate. The pesticides DRASTIC index ranges between 83 and 154, which is higher than the standard DRASTIC index. The resulted map of this version of DRASTIC clearly shows that significant parts (84\%) of the study area has moderate vulnerability to contamination, and only small parts of the study area have low vulnerability to pollution (about $16 \%$ ). The moderate vulnerability area 
Fig. 11 DRASTIC rating maps
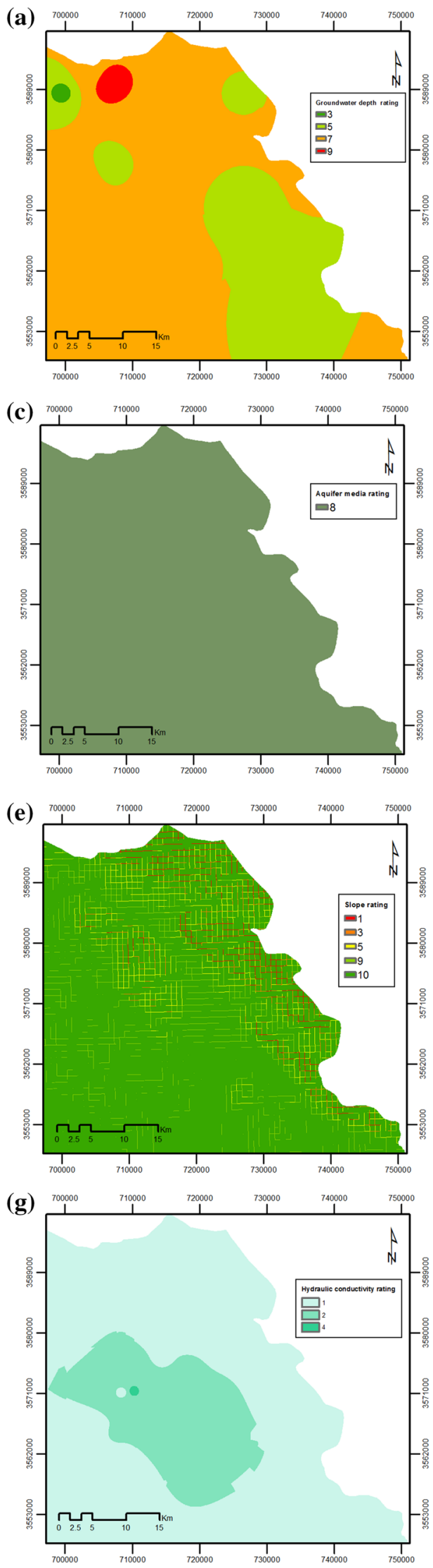

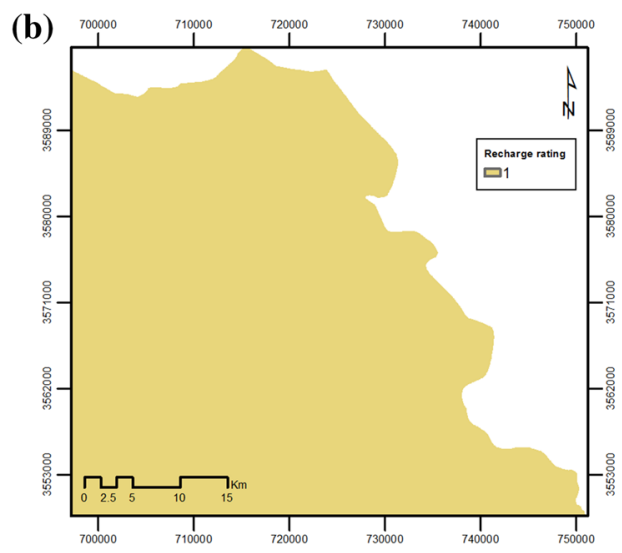

(d)

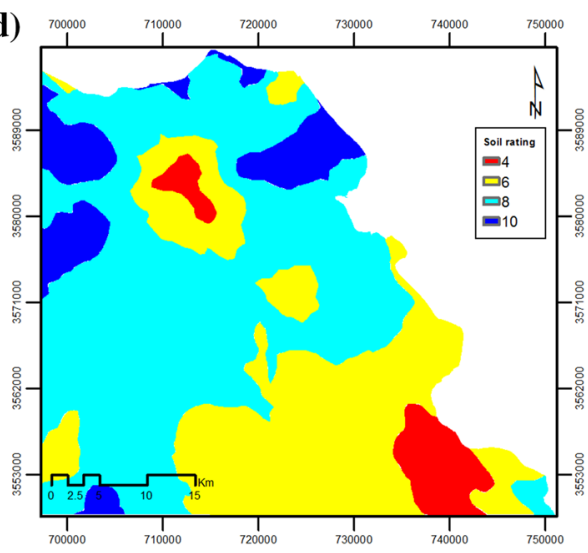

(f)

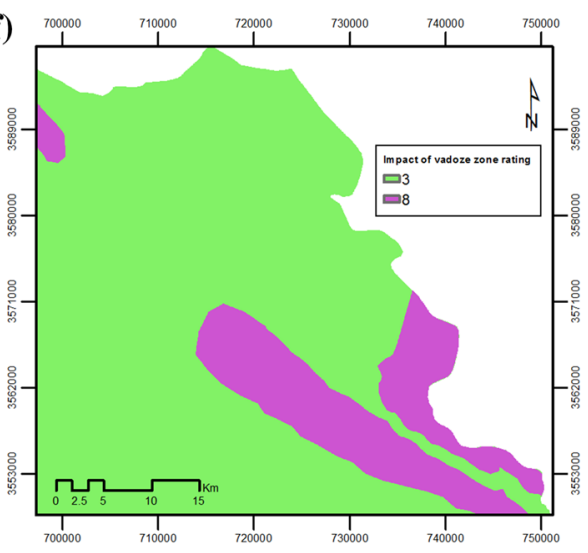




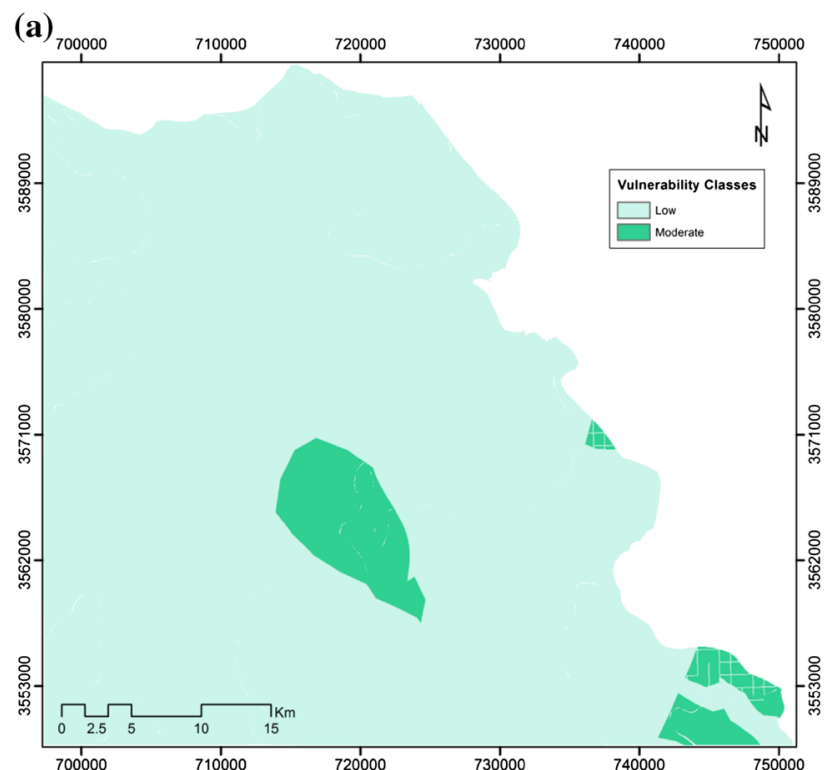

(b)

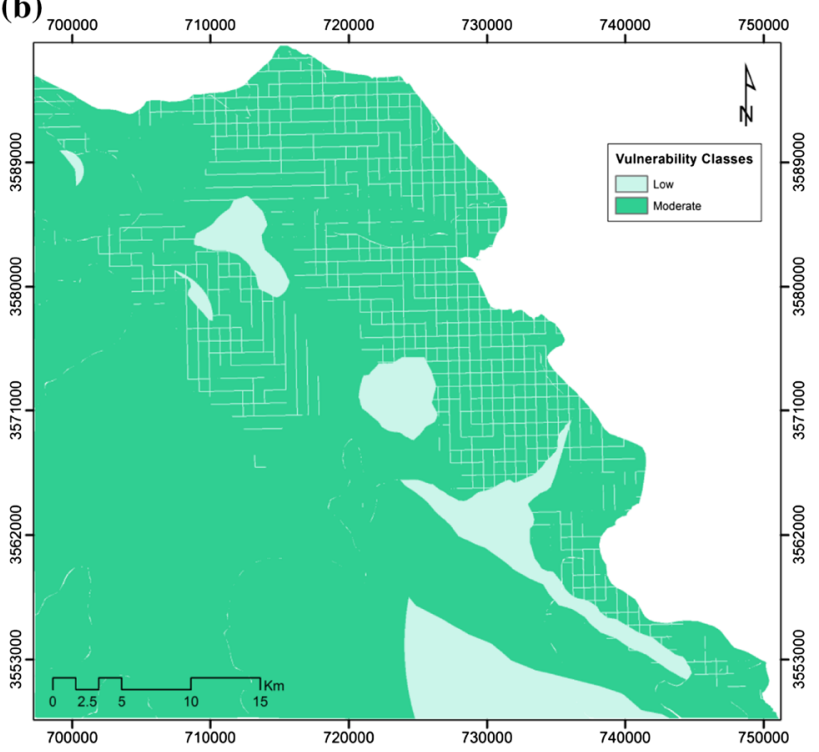

Fig. 12 Intrinsic aquifer vulnerability of the study area a general contamination $\mathbf{b}$ pesticides

Table 4 Vulnerability classes of the study area

\begin{tabular}{lllr}
\hline DRASTIC version & Vulnerability classes & \multicolumn{2}{c}{ Area occupied } \\
\cline { 3 - 4 } & & $\mathrm{km}^{2}$ & \multicolumn{1}{c}{$\%$} \\
\hline Standard & Low & 0.94 & 1,749 \\
& Moderate & 0.06 & 107 \\
Pesticides & Low & 0.13 & 245 \\
& Moderate & 0.87 & 1,611
\end{tabular}

distributes unevenly through the area may relate to the variation on the impact of vadose zone and low values of hydraulic conductivity and net recharge.
Sensitivity analysis

Aquifer vulnerability assessment requires validation to reduce subjectivity in the selection of rating ranges and weight and to increase reliability (Ramos and Rodríguez 2003). Sensitivity analysis provides helpful information on the influence of rating and weighting values assigned to each parameter and helps hydrogeologist to judge the significance of subjectivity elements (Gogu and Dassargues 2000). There are two types of sensitivity analysis: map removal sensitivity analysis introduced by Lodwick et al. (1994) and the single-parameter sensitivity analysis introduced by Napolitano and Fabbri (1996). The map removal sensitivity measure identifies the sensitivity of the vulnerability map towards removing one or more map from vulnerability analysis. The measure can be expressed as:

$S_{i}=\left|\frac{v}{N}-\frac{v^{\prime}}{n}\right|$

where $S_{i}$ is the sensibility, $v$ and $v^{\prime}$ are the unperturbed and the perturbed vulnerability indices, respectively; $N$ and $n$ are the number of data layers used to compute $v$ and $v^{\prime}$. The calculated vulnerability index obtained by using all seven factors is considered as an unperturbed while the vulnerability computed using a lower number of data layers was considered as a perturbed one (Babiker et al. 2005). Another important measure that should be evaluated when assessing the vulnerability is the variation index. The variation index $v_{x i}$ can be computed from the following expression: (Gogu and Dassargues 2000).

$v_{x i}=\frac{v-v^{\prime}}{v}$

The negative value of this measure means that removal of factors increases the vulnerability values, thereby reducing the calculated vulnerability.

The single-parameter sensitivity measure has been developed to evaluate the impact of each of the DRASTIC factors on the vulnerability index. This analysis compares the effective weight of each input factor in each polygon with the 'theoretical' weight assigned by the analytic model. The effective weight of each polygon is obtained using the following formula:

$w=\left(\frac{P_{\mathrm{r}} P_{\mathrm{w}}}{v}\right) \times 100$

where $w$ refers to 'effective' weight for each factor, $P_{\mathrm{r}}$ and $P_{\mathrm{w}}$ are the rating and weighting values of each factor, and $v$ is defined previously.

Table 5 shows the statistical summary of the seven factors maps used to compute the DRASTIC index. The high risk of groundwater contamination in the study area originates from the impact of vadose zone, soil media, 
Table 5 A statistical summary of the DRASTIC factor maps

\begin{tabular}{llcll}
\hline Factor & Min & Max & Mean & Standard deviation \\
\hline$D$ & 3 & 9 & 6.41 & 0.98 \\
$R$ & 1 & 1 & 1 & 0 \\
$A$ & 8 & 8 & 8 & 0 \\
$S$ & 4 & 10 & 7.32 & 1.43 \\
$T$ & 1 & 10 & 9.72 & 1.23 \\
$I$ & 3 & 8 & 3.81 & 1.88 \\
$C$ & 1 & 4 & 1.20 & 0.43 \\
\hline
\end{tabular}

Table 6 Statistics on sensibility to removing one DRASTIC factor

\begin{tabular}{lrrcl}
\hline Factor removed & Min & Max & Mean & Standard deviation \\
\hline$D$ & 0 & 4 & 1.92 & 0.71 \\
$R$ & 11 & 18 & 14.1 & 1.31 \\
$A$ & 0 & 2 & 0.76 & 0.45 \\
$S$ & 0 & 2 & 0.95 & 0.37 \\
$T$ & 1 & 4 & 1.7 & 0.49 \\
$I$ & 0 & 4 & 1.2 & 1.02 \\
$C$ & 1 & 4 & 2.7 & 0.57 \\
\hline
\end{tabular}

topography, and depth to groundwater level factors (mean values are $1.88,1.23,1.43$, and 0.98 ). The other factors imply low risks of contamination. The low variability of the factor implies smaller contribution to the variation of the vulnerability index across the study area.

Table 6 shows the statistic on sensitivity of removing one DRASTIC parameter on the obtained vulnerability values. It can be seen from this table that the most sensitive parameter was $R$ (net recharge) with a mean value of 14.1 followed by $C, D, T$, and $I$ with mean values of $2.7,1.92$, 1.7 , and 1.2 , respectively. With respect to the variation index (Table 7), all obtained values are positive which means that vulnerability index was reduced by removing one parameter of DRASTIC method and thereby increasing the calculated vulnerability. Table 8 shows the statistic of the calculated effective weights for each DRASTIC factor. As can be seen from this table, the effective weights of the DRASTIC factors exhibited some deviation from 'their theoretical' weights. This deviation is high in the R, S, and $\mathrm{T}$ parameters. The significance of these factors highlights the importance of obtaining accurate, detail, and reprehensive information about these factors.

\section{Conclusions and recommendations}

In this study, DRASTIC based-GIS technique is used to investigate the groundwater vulnerability of the principal aquifer in the southeastern Missan governorate, south of
Table 7 Variation index of the excluded DRASTIC factors

\begin{tabular}{lll}
\hline Factor removed & Mean & Standard deviation \\
\hline$D$ & 0.26 & 0.045 \\
$R$ & 0.013 & 0.014 \\
$A$ & 0.18 & 0.020 \\
$S$ & 0.09 & 0.016 \\
$T$ & 0.04 & 0.019 \\
$I$ & 0.13 & 0.080 \\
$C$ & 0.016 & 0.018 \\
\hline
\end{tabular}

Table 8 Statistics of the single parameter-sensitivity analysis

\begin{tabular}{lllc}
\hline Factor & $\begin{array}{l}\text { Theoretical } \\
\text { weight }\end{array}$ & $\begin{array}{l}\text { Theoretical weight } \\
(\%)\end{array}$ & $\begin{array}{l}\text { Effective weight } \\
(\%)\end{array}$ \\
\hline$D$ & 5 & 21.7 & 31.5 \\
$R$ & 4 & 17.4 & 3.94 \\
$A$ & 3 & 13.0 & 23.69 \\
$S$ & 2 & 8.7 & 14.47 \\
$T$ & 1 & 4.3 & 9.57 \\
$I$ & 5 & 21.7 & 18.47 \\
$C$ & 3 & 13.0 & 3.64 \\
\hline
\end{tabular}

Iraq. The obtained results show that the principal aquifer is naturally protected from the source of contaminants occurs in the surface, where the class of very low and low vulnerability classes extend over a large area of the study area (about $99 \%$ ). The moderate vulnerability class is associated with the uses of pesticides which is quickly dissolved and transport through the vadose zone and reaches groundwater reservoir. To protect groundwater reserve from contamination, a protective measure must be put before the beginning of exploiting the aquifer for comprehensive agricultural activities in the area. The use of biological method is preferred instead of using pesticides to protect groundwater especially in the moderate class of vulnerability.

Open Access This article is distributed under the terms of the Creative Commons Attribution License which permits any use, distribution, and reproduction in any medium, provided the original author(s) and the source are credited.

\section{References}

Al-Abadi AM (2011) Hydrological and hydrogeological analysis of northeastern Missan governorate, south of Iraq using geographic information system. Unpublished Doctoral thesis, Baghdad University

Al-Jaburi HK (2005) Hydrogeological and hydrochemistry study fro Ali-Al Gharbi area, Missan Governorate. Plate No. NI-39-16, 1:25000 scale, State Company of Geological Survey and Mining, Baghdad (in Arabic) 
Aller L, Bennett T, Lehr J, Petty R, and Hackett G (1987) DRASTIC: A standardized system for evaluation ground water pollution potential using hydrogeological settings. National Water Well Association, Dublin, Ohio and Environmental Protection Agency, Ada, Ok.EPA-600/2-87-035

Al-Siddiki AA (1978) Subsurface geology of southeastern Iraq. In: 10th Arab Petroleum Congress, Tripoli, Libya

Babiker IS, Modamed AA, Hiyama T, Kato K (2005) A GIS-based DRASTIC model for assessing aquifer vulnerability in Kakamigahara Heights, Gifu Prefecture, central Japan. Sci Total Environ 345:127-140

Bellen RCV, Dunnington HV, Wetzel R, and Morton D (1959) LexiqueStratigraphique Internal Asie. Iraq. Intern. Geol. Conger. Comm. Stratig, 3, Fasc. 10a

Buday T, Jassim SZ (1987) The regional geology of Iraq, vol. 2: tectonism, magmatism, and metamorphism. Publication of GEOSURV, Baghdad

Civita M (1994) La carte dellavulnerbilità deli aquiferialĺinquinamento: teoria e pratica. PitagoraEditrica, Bologan, Italy (in Italian)

Civita M, De Regibus C (1995) Sperimentazione di alcunemetdologie per la valutazionedellavulnerabilitàdegli aquifer. Q Geol Appl Pitagora Bologna 3:63-71

Corniello A, Ducci D, Napolitano P (1997) Comparison between parametric methods to evaluate aquifer pollution vulnerability using GIS: an example in the Piana Company, Southern Italy. In: Marinos P, Koukis G, Tsiambaos G, Stournaras G (eds) Engineering Geology and the Environmental. Balkema, Rotterdam, pp 1721-1726

Daly D, Dassargues A, Drew D, Dunne S, Goldscheider N, Neales S, Popescu CH, Zwahlen F (2002) Main concepts of the "European Approach" for karst groundwater vulnerability and assessment and mapping. Hydrogeol J 10(2):340-345

Doerfliger N, Zwahlen F (1997) EPIK: a new method for outlining of protection areas in karstic environment. In: Günay G, Johnson AL (eds) International symposium and field seminar on "karst waters and environmental impacts". Antalya, Turkey. Balkema, Rotterdam, pp 117-123

Foster SSD (1987) In Vulnerability of soil and groundwater to pollutions: proceedings and information. In: Van Duijvedbooden W, van Waegeningh HG (eds) Fundamental concepts in aquifer vulnerability pollution risk and protection strategy. TNO Committee on Hydrological Research, The Hague, pp 69-86

Gogu RC, Dassargues A (2000) Current trends and future challenges in groundwater vulnerability assessment using overlay and index methods. Environ Geol 39:549-559

Jassim SZ, Goff JC (2006) Geology of Iraq. Dolin, Prague and Moravian Museum, Brno, Czech Republic

Jassim SZ, Karim SA, Basi M, Al-Mubarak MA, Munir J (1984) Final report on the regional geology survey of Iraq, vol. 3, Stratigraphy. Manuscript report, Geological Survey of Iraq

Jessica EL, Sonia T (2009) Groundwater vulnerability assessments and integrated water resource management. Watershed Manag Bull 13(1):18-29

Khalaf F, Al-Kadi A, Al-Saleh S (1985) Mineralogical composition and potential sources of dust fallout deposits in Kuwait. North Arabian Gulf Sed Geol 42:255-278
Lazim SA (2002) The possibility of using groundwater formations (Bai-Hassan and Mukdadiyah) in Bazurgan area-the economic evaluation and suitability for human and industrial usage. Master thesis, University of Baghdad, p 99

Lodwick WA, Monson W, Svoboda L (1994) Attribute error and sensitivity analysis of map operations in geographical information systems: suitability analysis. Int $\mathbf{J}$ Geogr Inf Syst 4(4):413-428

Napolitano P, Fabbri AG (1996) Single-parameter sensitivity analysis for aquifer vulnerability assessment using DRASTIC and SINTACS HydroGIS 96: application of geographical information systems in hydrology and water resources management. In: Proceedings of Vienna Conference. IAHS Pub. vol 325, pp 559-566

Naqib KM (1967) Geology of the Arabian Peninsula, southeastern Iraq. USGS Professional, Paper No. 560-G

National Research Council (1993) Ground water vulnerability assessment, contamination potential under conditions of uncertainty. National Academic Press, Washington DC

Parsons RM (1956) Ground-water resources of Iraq.Khanaqin-Jassan area, vol 1. Development Board, Ministry of Development Government of Iraq, Baghdad

Popescu IC, Gardin N, Brouyére S, Dassargues A (2008) Groundwater vulnerability assessment using physically-based modeling: from challenges to pragmatic solutions. In ModelCARE 2007 proceedings, calibration and reliability in groundwater modeling. Refsgaard JC, Kovar K, Haarder E, Nygaard E (eds), Denmark.IAHS Publication No. 320

Ramos JA, Rodríguez R (2003) Aquifer vulnerability mapping in the Turbio river valley, Mexico: a validation study. GefoísicaInternacional 42(1):2002

Rundquist DC, Rodekohr DA, Peters AJ, Ehrman LDi, Murray G (1991) Statewide groundwater-vulnerability assessment in Nebraska using the DRASTIC/GIS model. Geocarto Int 2:51-58

Tesoriero AJ, Inkpen EL, Voss FD (1998) Assessing ground-water vulnerability using logistic regression. In: Proceedings for the source water assessment and protection 98 Conference, Dallas, TX, pp 157-165

Thapinta A, Hudak PF (2003) Use of geographic information systems for assessing groundwater pollution potential by pesticides in Central Thailand. Enviro Int 29(1):87-93

Van Stempvoort D, Ewert D, Wassenaar L (1993) Aquifer vulnerability index: a GIS-compatible method for groundwater vulnerability mapping. Can Water Resour J 18(1):25-37

Vieux BE (2004) Distributed Hydrologic Modeling Using GIS.Water Science and Technology Library, vol 48. Kluwer Academic Publishers, Norwell

Von Hoyer M, Söfner B (1998) Groundwater vulnerability mapping in carbonate (karst) areas of Germany, Federal institute for geosciences and natural resources, Archive no. 117854, Hanover, Germany

Vrba I, Zaporozec A (1994) Guidebook on mapping ground-water vulnerability. International Association of hydrogeologist, Heise, Hannover. International Contributions to Hydrogeology No.16 